\title{
Nový postup EU pro posílení právního státu
}

\section{EU Framework to Strengthen the Rule of Law}

\author{
David Sehnálek*
}

\begin{abstract}
Abstrakt
Článek pojednává o novém postupu Evropské unie pro posíleni právního státu. Tento nově navrbovaný mechanismus je nejprve srovnáván s jinými dosavadnimi mechanismy pro prosazováni unijního práva. Zkoumán je prìtom jak z pobledu právníbo, tak i politického. Problém totiž spočivá ve skutečnosti, že postup

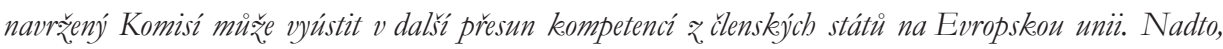
závažné a politicky citlivé spory by dle Komise měly být roz̧hodovány Komisí samou, tedy orgánem politickým, a proto nesoudním. Argumenty, že navrbovaný mechanismus príspivá ke právni jistotè clenskejch

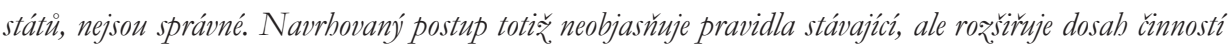
Evropské unie o nové oblasti.
\end{abstract}

\section{Klíčová slova}

Právni stát; řžení pro porušeni povinnosti; Komise; infringement.

\begin{abstract}
The article describes and analyzes new EU framework to strengthen the rule of Law. This mechanism is compared to the other current infringement proceedings. Legal as well as political question are addressed. The problem is that the Commission proposal may cause a de facto shift in competences that have been transferred to the European Union. In addition to that, the Commission, as a political organ, shall not solve problems of judicial character. The mechanism also does not contribute to the legal certainty and probibition of arbitrariness of the executive powers since it does not clarify existing rules, but rather extends them beyond the original intention of Member states.
\end{abstract}

\section{Keywords}

Rule of Law; Enforcement Procedures; Commission; Infringement.

\section{1 Úvod}

Evropská unie je mezinárodní organizací vybavenou vcelku efektivními nástroji prosazování práva vůči jejím členským státům. Základní mechanismus prosazování unijního práva obsažený v článku 258 Smlouvy o fungování EU (dále jen „SFEU“) je v tuzemské literatuře dobře uchopen a popsán kvalitně a podrobně ve všech základních učebnicích unijního práva. Vedle tohoto mechanismu však existují další, specifické postupy prosazování unijního práva, které již zpravidla pro svůj relativně omezený význam stojí

\footnotetext{
* JUDr. David Sehnálek, Ph.D., odborný asistent, Katedra mezinárodního a evropského práva, Právnická fakulta Masarykovy univerzity, Brno / assistant professor, Department of International and European Law, Faculty of Law, Masaryk University, Brno, Czech Republic / orcid.org/0000-0001-8763-7570 / E-mail: davy@mail.muni.cz
} 
stranou hlavní pozornosti odborné literatury. ${ }^{1}$ Jedním z nich je i postup upravený v článku 7 Smlouvy o EU (dále jen „SEU“), jehož účelem je zajištění ochrany základních práv a svobod definovaných článkem 2 SEU. Tento institut dosud nebyl ve své relativně krátké historii použit. ${ }^{2}$ Jeho význam přesto stoupá, a to z důvodů politického vývoje $\mathrm{v}$ řadě členských států. Ten se totiž začíná velmi výrazně rozrůzňovat v závislosti na tom, jakým výzvám ta která země čelí a představám jejich občanů a politické reprezentace o jejich vhodném řešení. Vznikají více či méně odůvodněné pochybnosti o tom, nakolik jsou určité postupy orgánů členských států, které sice mohou být důsledkem formálně demokratických procesů v těchto státech, skutečně v souladu s vnitrostátním i unijním pojetím právního státu. ${ }^{3}$ Vzrůstá tak snaha řešit sporné situace nejen uvnitř daných států, ale i prostřednictvím vnějších mechanismů, tedy též na úrovni Evropské unie. Za této situace Komise připravila iniciativu, která by měla vést $\mathrm{k}$ nastavení procesu administrativního řešení situací věcně spadajících pod článek 7 SEU. V souvislosti s aktuálním politickým děním po volbách v roce 2015 v Polsku se otevřela debata, zda mechanismus obsažený v článku 7 SEU aktivovat a do dění v Polsku zasáhnout. ${ }^{4}$ Cílem tohoto článku je prozkoumat postup využití článku 7 SEU navržený Komisí (dále též „,postup EU pro posílení právního státu“) a identifikovat slabiny jí zvoleného řešení.

\section{Představení jednotlivých mechanismů prosazování práva v Evropské unii}

Než se pustíme do vlastní analýzy postupu EU pro posílení právního státu, bude vhodné představit též právní a politické souvislosti zkoumaného problému. V primárním právu

1 Nikoliv již stranou zájmu odborné právnické veřejnosti vůbec. K problematice právního státu se konala dne 31. řijna 2014 konference PRÁVNÍ STÁT A MECHANISMY JEHO OCHRANY V EVROPĚ ČESKÁ PERSPEKTIVA, která byla pořádána Právnickou fakultou v Praze ve spolupráci se Sekcí pro evropské záležitosti Úřadu vlády ČR.

2 Zaveden byl Amsterodamskou smlouvou, v platnost tedy vstoupil v roce 1999.

3 Zásada právního státu by měla zaručovat, že veškeré veřejné pravomoci budou vykonávány v mezích stanovených právem, v souladu s hodnotami demokracie, základních práv a svobod a pod kontrolou nezávislých a nestranných soudů. Pojetí se mezi členskými státy může lišit, základ je ale společný. Na úrovni Evropské unie je s pojetím právního státu úzce spojena řada hodnot a norem. Patř́ mezi ně zákonnost, která předpokládá průhledný, odpovědný, demokratický a pluralistický proces přijímání zákonů; právní jistotu; zákaz svévole výkonné moci; nezávislé a nestranné soudy; účinný soudní přezkum zahrnující respekt k základním právi̊m; a rovnost před zákonem. Viz SDĚLENÍ KOMISE EVROPSKÉMU PARLAMENTU A RADĚ Nový postup EU pro posílení právního státu /*COM/2014/0158 final */ odst. 2. [online]. [cit. 2016-01-23]. Dostupné z: http://eur-lex.europa.eu/legal-content/CS/ TXT/?uri=celex:52014DC0158

4 Polsko přitom není jediným státem, kde byla otázka možnosti zásahu ze strany Evropské unie pro možné porušení hodnot právního státu zvažována. Dalšími státy bylo Rakousko, Francie, Rumunsko a Mad’arsko. Viz Article 7 TEU: A Mechanism To Protect EU Values Law [online]. [cit. 2016-01-23]. Dostupné z: http://epthinktank.eu/2013/10/07/article-7-teu-a-mechanism-to-protect-eu-values/ 
Evropské unie lze $\mathrm{v}$ tuto chvíli identifikovat tři mechanismy prosazování práva ${ }^{5}$ vưči členským státům.

Základním a obecným postupem prosazování unijního práva je postup definovaný v článcích 258 a 259 SFEU. Věcně lze tento postup použít proti členskému státu v príípadě porušení jakékoliv ,povinnost[i], keterá pro něj ze Smluv vyplývá, samozřejmě pokud Smlouvy nestanoví jinak. Charakteristický je tím, že je standardně dvoufázový, předpokládá totiž nejdříve správní řízení vedené proti dotčenému členskému státu ze strany Komise a teprve následní soudní řízení před Soudním dvorem EU. Tento časově náročný mechanismus je v několika prrípadech stanovených Smlouvami modifikován a zjednodušen vynecháním správního řízení, kdy sporná záležitost může být Soudnímu dvoru předložena př́mo. ${ }^{7} \mathrm{Na}$ tato ustanovení navazuje úprava obsažená v článku 260 SFEU, která Soudnímu dvoru umožňuje členské státy postihnout sankcí finanční povahy. ${ }^{8}$

Druhý postup je upraven článkem 126 SFEU a týká se věcně velmi omezeného okruhu sporů zapříčiněných porušením pravidel rozpočtové odpovědnosti. I zde je významná role Komise, což je tomuto postupu společné s postupem obecným. Vlastní řešení sporů ale bylo svěřeno Radě. Rozdíl je tedy zásadní. Rada není nadstátním orgánem, nemá též nezávislé a nestranné postavení. A konečně není orgánem soudním. Mechanismus má proto koncepčně mezivládní charakter, je politický, čemuž ostatně odpovídá i praxe jeho (ne)uplatňování.

Třetí postup je již zmíněný postup pro posílení právního státu upravený v článku 7 SEU. Věcně se dotýká pouze situace, kdy se členský stát dopustí závažného porušení článku 2 SEU. 'Toto ustanovení identifikuje základní hodnoty sdílené členskými státy a stanoví, že je Unie na těchto hodnotách založena. Zde nám tedy vystupuje do popředí první zásadní znak postupu dle článku 7 SEU, který je zcela odlišný od ostatních výše popsaných

5 Pojem ,právo“ bez bližšího zúžení na právo unijní zde byl použit zcela záměrně z důvodů, které budou vysvětleny dále v textu.

6 Viz článek 258 odstavec 1 SFEU a obdobně též článek 259 odstavec 1SFEU.

7 Např. v př́padě veřejných podpor dle článku 108 odstavce 2 SFEU, dále v př́padě stanoveném v článku 348 SFEU, tedy v záležitostech, jež by mohly být označeny jako zneužití nástrojů ochrany národní bezpečnosti a dle článku 114 SFEU v prípadě zneužití pravomoci členského státu zavést vnitrostátní předpisy odchylující se od řešení harmonizovaného Evropskou unií nástrojem prrijatým na právním základu článku 114 SFEU.

8 Podrobný rozbor viz např. DASHWOOD, A. a R. WHITE. Enforcement Actions Under Articles 169 and 170 EEC. European Law Review. Roč. 1989, č. 14. s. 388-411.

9 Dle tohoto ustanovení platí, že: „Unie je založena na hodnotách úcty k lidské dìstojnosti, svobody, demokracie, rovnosti, právního státu a dodř̌ováni lidských práv, věetně práv prǒslušniku menšin. Tyto hodnoty jsou společné členským státům ve společnosti vyznačujicí se pluralismem, nepröpustností diskriminace, tolerancí, spravedlností, solidaritou a rovností žen a mužu. "Z obsahu citovaného článku vyplývá, že jeho věcný dosah je širší, než by se na první pohled z označení zkoumaného mechanismu mohlo zdát. V rámci postupu pro posílení právního státu totiž mohou být prosazovány veškeré hodnoty v článku 7 SEU uvedené, a tedy ne jen samotný právní stát. 
postupů. Ty umožňují prosazovat unijní právo vytvořené členskými státy nebo přijaté v oblastech přenesených pravomocí, a to v rámci pravomocí Evropské unie. Mechanismus článku 7 SEU naproti tomu slouží k prosazování hodnot uplatňovaných horizontálně, v rámci jakékoliv činnosti členského státu. Tedy i mimo oblast pravomocí Evropské unie.

Bližší pohled na článek 7 SEU ukazuje, že uvedené ustanovení ve skutečnosti upravuje dvě procedury. Věcně se obě dotýkají téhož, tedy závažného porušení hodnot stanovených článkem 2 SEU. Procedura první ale slouží jako nástroj předběžné ochrany, tj. uplatní se v př́ípadě, že k závažnému porušení ještě nedošlo, zatímco druhá je využitelná v př́padě kdy k závažnému porušení již došlo a toto trvá. Možnost předběžné reakce ještě předtím, než k porušení dojde, představuje druhou zásadní odlišnost od výše popsaných mechanismů, v jejichž případě se kontrolní mechanismy aktivují teprve ex post.

Třetí zásadní odlišnost spočívá v subjektech zapojených do řešení prrípadného porušení hodnot stanovených článkem 2 SEU. Procedura předběžné ochrany může být iniciovaná nejen tradiční Komisí a členskými státy, ale též Evropským parlamentem a pravomoc rozhodovat byla svěrena Radě. Procedura druhá mưže být iniciována tradičně členskými státy nebo Komisí, rozhodování ale bylo určeno Evropské radě. Role Evropského parlamentu je v tomto př́padě odlišná, jeho souhlas je totiž nezbytným předpokladem pro následné prüijetí rozhodnutí.

Čtvrtá zásadní odlišnost spočívá v roli Komise. Společná je sice její iniciační pravomoc. Ona je klíčovým orgánem, který zahajuje vlastní fázi řešení sporu jiným k tomu určeným orgánem, tedy Soudním dvorem, Radou nebo Evropskou radou. Rozdílná je ale úprava jejího postupu před využitím této pravomoci. První dva mechanismy prrímo v primárním právu zdůrazňují roli Komise jako orgánu, který má členské státy nejen hlídat a kontrolovat, ale také $\mathrm{v}$ prrípadě zjištění problému usilovat o zajištění nápravy ještě před vlastním řešením sporu. Článek 7 SEU naproti tomu takovou roli Komisi nepřiznává.

\section{Nový postup EU pro posílení právního státu - právní analýza}

Jak již bylo uvedeno, článek 7 SEU neupravuje fázi, která je v př́padě řízení pro porušení povinnosti upravenému v článcích 258 až 260 označována jako správní řízení a která předchází řízení soudnímu. Komise této možnosti aktivně využila a vypracovala sdělení, ${ }^{10}$ ve kterém navrhla možnou regulaci postupu, který by principiálně znamenal představení mechanismů známých z řízení pro porušení povinnosti dle článků 258 a 259 SFEU i do oblasti pokryté článkem 7 SEU. Ve zkratce - Komise předpokládá, že by s členským státem, který porušuje hodnoty zakotvené v článku 2 SEU, vedla neformální řízení, jež by zahrnovalo tři dílčí kroky. V prvním by Komise posuzovala daný

10 Sdělení Komise Radě a Evropskému parlamentu o článku 7 Smlouvy o Evropské unii: Respektování a podpora hodnot, na kterých je Unie založena $(\operatorname{KOM}(2003) 606$ v konečném znění ze dne 15. ř́jjna 2003). 
stát, pokud by toto nebylo dostatečné, pak ve druhém kroku by daný stát vyzývala k zajištění nápravy s tím, že by mohla poskytnout i pokyny směřující ke konkrétnímu řešení. Ve třetím kroku by bylo prováděno sledování daného státu za účelem zhodnocení, zda byla zajištěna náprava. $\mathrm{V}$ př́padě, že by tomu tak nebylo, by mohl následovat postup kodifikovaný článkem 7 SEU.

Postup byl popsán zkráceně, nicméně podstata byla vystižena a pro další rozbor podrobnější popis není nutný. ${ }^{11}$ Přejděme proto k vlastní právní analýze postupu navrženého Komisí.

V prvé řadě je nutné zdůraznit, že navržený mechanismus, i kdyby byl uplatňován, není právně závazný. Sdělení není pramenem práva a Evropské unii chybí v současné době pravomoc, která by jí umožnila předpis tohoto druhu př́ijmout. Potažmo i sama Komise nemůže přijmout právně závazný akt regulující takovou problematiku. Výslovný právní základ pro takový postup ve Smlouvách chybí. Využití článku 352 SFEU potom nepřichází v úvahu, jelikož toto ustanovení je sice obecné povahy, ale týká se výhradně situací, kdy Unie má Smlouvami definovaný cíl, tento cíl je věcně podřaditelný pod některou z politik, která musí být opět Smlouvami upravena a teprve pak je možné, chybí-li jiné ustanovení zakládající legislativní pravomoc, daný akt přijmout. ${ }^{12}$

Ochrana hodnot definovaných článkem 2 SEU v členských státech není cílem Evropské unie. Není sice pochyb, že tyto hodnoty pro Unii jsou významné, a to i ve vztahu k členským státům. Jejich dodržování je ostatně předpokladem členství v Evropské unii. ${ }^{13}$ Evropská unie ale nebyla založena jako lidskoprávní mezinárodní organizace typu Rady Evropy. Článek 7 proto není možné chápat jako ustanovení, které by Evropskou unii mělo agendou k Radě Evropy přibližovat, ale spíše jako svého druhu pojistku před nepředvídanou změnou politické situace $\mathrm{v}$ některém z členských států.

Jak už bylo uvedeno, dodržování hodnot zakotvených v článku 2 SEU je předpokladem členství v Evropské unii. Nadto, řada politik a činností Evropské unie je přímo prováděna členskými státy a jejich orgány, zcela zřetelné je to v oblasti soudního prosazování práva, které prrímo funkčně závisí na národních soudních soustavách. Demokratické fungování členského státu a zachovávání zásad fungování právního státu je proto conditio sine qua non řádného fungování Evropské unie v tomto státě. Dodržování těchto hodnot je tedy povinností nejen při vstupu, ale mělo by mít přetrvávající charakter po celou dobu členství v Evropské unii.

$11 \mathrm{~V}$ př́padě zájmu o podrobnější informace viz COMMUNICATION FROM THE COMMISSION TO THE EUROPEAN PARLIAMENT AND THE COUNCIL. A new EU Framework to strengthen the Rule of Law [online]. [cit. 2016-01-23]. Dostupné z: http://ec.europa.eu/justice/effective-justice/ files/com_2014_158_en.pdf

12 Článek 352 SFEU je nepravděpodobným právním základem i z hlediska faktického. Předpokládá totiž jednomyslný souhlas všech členských států. Ten je u námi zkoumaného problému těžko představitelný.

13 Viz článek 49 SEU. 
Unie sama, jakož i členské státy nemají žádné nástroje, jak členský stát ze svého středu „umravnit“ $v$ prípadě, kdy tento stát přestal tyto hodnoty respektovat. Vyloučení z Unie není právně možné a nelze předpokládat, že porušující stát bude mít zájem sám dobrovolně z Unie vystoupit. Typicky federální řešení situace ingerencí federální moci za dočasného nahrazení moci státní ${ }^{14}$ pak nepřichází v úvahu nejen právně, ale i fakticky a politicky. Mechanismus článku 7 SEU proto může být nahlížen jako jediný prostředek ochrany v situaci tohoto druhu. Je to prostředek ultimátní, přesto relativně neškodný, ne však bezzubý. Jeho význam spočívá již v jeho existenci a jeho síla bude zřetelná v rovině politické. Ostatně, i řízení pro porušení povinnosti až do Maastrichtské smlouvy nebylo završeno možností trestání státu a přesto bylo relativně účinným nástrojem prosazování práva. ${ }^{15}$ Mechanismus obsažený v článku 7 již jen z tohoto srovnání vychází lépe, neb sankci v podobě omezení členských práv zná. ${ }^{16}$

Komisí navržené řešení má perspektivu stát se významným politickým nástrojem prosazování práva v členských státech přímo Evropskou unií. Politické hledisko přitom nelze podceňovat. Statistiky totiž prokazují jeho efektivitu v praxi. ${ }^{17} \mathrm{Za}$ povšimnutí proto stojí fakt, že podle článku 7 SEU mají v rovině iniciační Komise, členské státy a v dosahu předběžné kontroly též Evropský parlament rovné postavení. Zavedením a akceptací iniciačního postupu se toto rovné postavení mění výrazně ve prospěch Komise. Úplné vyloučení ostatních subjektů s aktivní legitimací ve prospěch Komise např. s poukazem na estoppel sice s ohledem na jasnou kodifikaci jejich postavení v právu primárním nepřichází v úvahu. Nebezpečí směrem do budoucna, kdy by nově nastavený faktický stav mohl být v primárním právu kodifikován, ale nelze podceňovat. Nebylo by to ostatně v historii Evropské unie poprvé. ${ }^{18}$

14 Srov. např. KŘEPELKA, F. Prenos, doprovod a zoblednèni evropského práva českým právem. 1. vyd. Brno: Masarykova univerzita - Právnická fakulta, 2010, s. 35, 125 s. Acta Universitatis Brunensis Iuridica č. 364. ISBN 978-80-210-5066-2.

15 Uvedené tvrzení samozřejmě neplatí absolutně. K problémům, které s tehdejší nastavením řízení pro porušení povinnosti byly spojeny viz např. WAGENBAUR, R. How to Improve Compliance with European Community Legislation and the Judgments of the European Court of Justice, 19 Fordham International Law Journal (1995-1996), s. 939 a násl.

16 Na straně druhé nelze přeceňovat ani význam a odstrašující efekt pokut ukládaných dle článku 260 SFEU. Viz např. WENNERÅS, P. ,Sanctions against Member States under Article 260 TFEU: Alive, but not kicking?‘ (2012) 49 Common Market Law Review, Issue 1, s. 145-175.

17 Statistická data ukazují, že Komise je statisticky poměrně úspěšná v prosazování práva vůči členským státům. Náprava je často zajištěna již ve fází správního řízení, to znamená ze strany členského státu dobrovolně, bez existence závazného rozhodnutí, kterým by povinnost zjednání nápravy byla uložena. Politickou rovinu prosazování unijního práva proto nelze podceňovat. Viz Kontrola uplatňování práva Unie: Výroční zpráva za rok 2014: Komise [online]. [cit. 2016-01-23]. Dostupné z: http://ec.europa.eu/ atwork/applying-eu-law/docs/annual_report_32/com_2015_329_cs.pdf, s. 16.

18 Soudní dvůr EU již dovodil aktivní legitimaci Evropské parlamentu v situaci, kdy tato nebyla přiznána Smlouvou o založení Evropského hospodářského společenství, což následně vedlo ke změně dotčené úpravy Maastrichtskou smlouvou. Členské státy v tomto případě jen následovaly legislativní vývoj, který proběhl v podstatě samovolně na komunitární úrovni. Viz rozsudek Soudního dvora ze dne 4. řína 1991. Evropský parlament proti Radě Evropských společenství. Věc C-70/88. 
Absence úpravy zvláštních pravomocí Komise, které by jí umožňovaly postup podobný tomu předvídanému články 126, 258 a 259 SFEU může být vnímána dvojím způsobem. Jednak mohla být záměrná, kdy členské státy přri koncipování tohoto mechanismu nehodlaly přespř́liš posilovat nadstátní charakter této procedury zvýrazňováním role orgánu zcela typicky nadstátní povahy. Druhý prrístup je patrný z obsahu sdělení Komise. Ta tuto absenci vnímá jako problematickou mezeru, která musí být vhodně vyplněna, ${ }^{19}$ a to nejlépe způsobem, který sama navrhuje.

Je asi pochopitelné, že Komise k problému prristupuje jako k př́ležitosti, zvlášt' má-li to být príležitost posílit své postavení a pravomoci. Věc má však i právní rozměr. Obě Smlouvy v řadě ustanovení at' už preambule či jednotlivých článků zdůrazňují princip svěřených pravomocí. ${ }^{20} \mathrm{~S}$ lehkou ironií řečeno - množství odkazů na tento princip už těžko lze považovat za náhodu. Za dané situace výslovná úprava určitého postupu a pravomocí Komise v rrízeních podle článků 126, 258 a 259 SFEU a absence této úpravy v čl. 7 naznačuje, že vưlí členských států bylo Komisi takovou pravomoc nesvěřit. Př́padné dovození takové pravomoci samotnou Unií postrádá oporu ve Smlouvách a je $\mathrm{v}$ rozporu s principem svěřených pravomocí. Řešením by proto mohla být pouze změna těchto smluv a výslovné zakotvení této nové pravomoci, či alespoň právního základu pro úpravu jejîho postupu sekundárním právem.

Funkčnost navrhovaného mechanismu je sporná i z jiného důvodu. Evropská unie má článkem 4 SEU stanovenou povinnost ctít národní identitu členských států. Národní identita zahrnuje mimo jiné též politický a ústavní systém daného členského a jejich organizaci. Výklad uvedeného ustanovení přitom dosud není plně ustálen. ${ }^{21}$ Dovozovat z něj nicméně lze existenci dvou přístupů členských států k základním otázkám pojetí právního státu. Těch, které jsou společné všem ostatním členským státům a těch, které takovýto obecný charakter nemají. Je dále zjevné, že toto ustanovení představuje limit činnosti Komise i při uplatňování postupu EU při prosazování právního státu. Zvládne však tento úřednický orgán správně vyhodnocovat právní problémy, které jsou nejlépe kvalifikovány řešit národní ústavní soudy a Soudní dvůr EU?

Dalším problematickým aspektem je představa Komise o její roli. Sdělení naznačuje, že její angažmá má být širší a přesahovat pouhé zjištění, zda došlo k porušení, či nikoliv. Komise dokonce předpokládá, že by členský stát od ní dostal určitý návod k řešení (jí sa-

19 Viz COMMUNICATION FROM THE COMMISSION TO THE EUROPEAN PARLIAMENT AND THE COUNCIL. A new EU Framework to strengthen the Rule of Law [online]. [cit. 2016-01-23]. Dostupné z: http://ec.europa.eu/justice/effective-justice/files/com_2014_158_en.pdf, s. 2 a násl.

20 Viz preambule Smlouvy o EU, článek 3 odstavec 6, článek 4 odstavec 1 a článek 5 odstavce 1 a 2 téže smlouvy, dále též článek 7 SFEU.

21 Srov. MOLEK, P. Materiálni obnisko ústavy: věcný limit evropské integrace? Brno: Masarykova univerzita, 2014, s. 246 a násl., 285 s. Edice Scientia 488. ISBN 978-80-210-7435-4. 
mou identifikovaného) problému. ${ }^{22}$ To je přitom mimořádně důležité. Důvodů je hned několik. Jednak je to totiž problém z hlediska interpretace obsahu hodnot zakotvených v článku 2 SEU. Soudní dvůr k tomu nemá podle stávající úpravy pravomoc. Komise je zase orgánem, který nemá povahu soudu. Komisí navržený postup tedy předpokládá, že správní orgán bude interpretovat jedno z ustanovení Smluv a směřovat členský stát k řešení, které Komise sama pokládá za správné. Z prostého žalobce se do určité míry stává arbitr. Je to sice malý, přesto znatelný posun těžiště v rozhodování o tom, jaké jednání státu je v souladu s článkem 2 SEU a jaké již nikoliv. Mění se tím výklad článku 7 SEU, který Komisi definuje jen jako jednoho z možných „žalobců“, tedy jako orgán bez vlastní rozhodovací pravomoci. ${ }^{23}$

Krom výše uvedeného právního hlediska je nezanedbatelné též hledisko politické. Bylo by optimistické v tento čas tvrdit, že Unie funguje jak má a že členské státy jsou bezvýhradně přesvědčeny o smysluplnosti a správnosti jednání jejích orgánů. Další angažmá a zásah do záležitostí tradičně státy považovaných za vnitřní pak je jen prriléváním oleje do ohně odporu vi̊či projektu evropské integrace. To za stavu, kdy to není nezbytně nutné, jelikož na mezinárodní úrovni již existují vhodné mechanismy řešení problémů např. v rámci Rady Evropy, ${ }^{24}$ či tyto problémy lze řešit i nadále tradičně, tedy diplomatickou cestou.

Další problém souvisí s nastavením hranice, která musí být překročena pro aktivaci mechanismu v článku 7 SEU. Komise ve své sdělení jasně a zřetelně připomíná, že „, $[m] e c h a-$

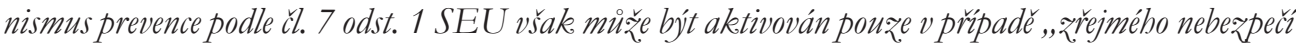
záva:̌nébo porušeni" a mechanismus sankci podle čl. 7 odst. 2 SEU pouze v prípadè „závažného a trvajicího porušeni" "hodnot uvedených v článku 2 SEU ze strany členského státu. Hranice pro aktivaci obou mechanismu clánku 7 SEU jsou velmi vysoké a zdurazñuji, že lze tyto mechanismy pouřit pouze jako posledni možnosti. “ Uvádí dále, že „¡p]osledni vývoj v některých členských státech ukázal, že tyto mechanismy nejsou vždy vhodné pro rychlou reakci na obrožení právního státu v členském státu. “25 Jinými slovy, Komise si je vědoma, že mechanismus předvídaný článkem 7 SEU je skutečně krajním a výjimečným prostředkem. Případné uplatňování postupu navrženého Komisí v jejím sdělení by však vedlo k faktickému rozšíření tohoto mechanismu i na situace, které př́isným podmínkám aplikace článku 7 SEU nevyhovují. Domníváme se nicméně, že by to bylo ve zjevném rozporu s účelem a smyslem tohoto ustanovení.

22 Viz COMMUNICATION FROM THE COMMISSION TO THE EUROPEAN PARLIAMENT AND THE COUNCIL. A new EU Framework to strengthen the Rule of Law, s. 8.

23 V tomto ohledu spočivá též odlišnost od řízení upraveného v článcích 126, 258 a 259SFEU. Podle těchto ustanovení totiž Komise není jen prostým ,žalobcem“, ale je jí svěřen úkol stát vést k nápravě. Nic takového v článku 7 SEU není, nový postup to ale může změnit.

24 Viz článek 8 Statutu Rady Evropy.

25 Viz SDĚLENÍ KOMISE EVROPSKÉMU PARLAMENTU A RADĚ Nový postup EU pro posílení právního státu /* COM/2014/0158 final */ [online]. [cit. 2016-01-23]. Dostupné z: http://eur-lex.europa.eu/legal-content/CS/TXT/?uri=celex:52014DC0158. 


\section{Doktrinální aspekty}

Jak je už pro Evropskou unii typické, v odůvodnění postupu Komise chybí byt' jen zmínka o doktrinálním přístupu k jí adresovanému problému. Zdůvodnění prujetí úpravy se omezuje jen na již zmíněné konstatování absence vhodného řešení, dále je zdůrazněna výjimečnost a „síla“ mechanismu dle článku $7 \mathrm{SEU}^{26}$ a tedy potřebnost řešení přiměřenějšího, jakož i fakt, že to byly právě členské státy, kdo Komisi o prrípravu nového postupu požádal. ${ }^{27}$ To vše jsou však pouze politické argumenty sledující výhradně faktické hledisko.

K problému je ovšem nutné přistoupit koncepčně. V oblasti, kde je uplatňována nadstátní metoda regulace a kde zároveň došlo k přenosu pravomocí, lze pochopit též existenci pravomoci určovat členským státům jejich povinnosti a rozhodovat na nadstátní úrovni o př́padných porušeních. Mimo oblast práva Evropské unie, a v prrípadě mechanismu dle článku 7 SEU se mimo regulovanou oblast skutečně ocitnout můžeme, je ovšem jakékoliv unijní „peskováni' politicky a právně problematické. Státy členstvím v Evropské unii neztrácejí zcela svou suverenitu, což nutně znamená, že vnitřní věci zůstávají jejích záležitostí. Vnitřní věci pak z pohledu Evropskou unie zahrnují vše, co členské státy na Unii Smlouvami nepřenesly. V našem př́padě je tedy podstatné, odkud Evropská unie dovozuje svou legitimitu a jak je definován její vztah k členským státům.

V př́padech mimo pravomoc Evropské unie, které se týkají porušení hodnot, jež se dotýkají takřka cele pouze a jenom daného státu a pouze okrajově nebo vůbec zasahují do záležitostí evropské integrace, by politická reprezentace takového státu měla nést důsledky takového svého jednání, jež je v rozporu se zásadami právního státu, v prvé řadě uvnitř tohoto státu, podle jeho vnitrostátního práva a politicky ve vztahu k jeho občanům. Evropská unie svou legitimitu odvozuje od občanů členských států a od těchto států samotných. Z pohledu států pak i nadále platí, že jsou to státy, kdo je pánem Smluv a tedy v konečném a krajním důsledku i Evropské unie. Z tohoto úhlu pohledu se aktivity Komise jeví jako nepřijatelné.

Přijmeme-li přístup federalistický, pak výše uvedené neplatí. Pro federace je charakteristické prosazování vlastního práva vưči dílčím státům, a to i v rovině ústavní. Stanovení určitých hodnot a jejich vymezení způsobem, který je Komisí dovozován ve vztahu

26 Samotné sdělení hovoří ve vztahu k článku 7 SEU o ,jaderné alternativě“. Je to termín, který lze nalézt i v odborné literatuře, viz např. KOCHENOV, D. a L. PECH Upholding the Rule of Law in the EU: On the Commission's 'Pre-Article 7 Procedure' as a Timid Step in the Right Direction. EUI Working Paper RSCAS 2015/24. ISSN 1028-3625 [online]. [cit. 2016-01-23]. Dostupné z: http://cadmus.eui.eu/ bitstream/handle/1814/35437/RSCAS_2015_24.pdf?sequence $=3$

27 Návrh iniciující diskuzi týkající se úlohy Evropské unie při ochraně lidských práv a právního státu přišel ze strany ministrů zahraničních věcí Německa, Dánska, Finska a Nizozemska v roce 2003. Viz DURICA, J. Podkladový materiál pro konferenci „Právni stát a mechanismy jeho ochrany v Evropě: česká perspektiva“, která se konala na prǎ̌ské Právnické fakultè 31. řjina 2014 [online]. [cit. 2016-01-23]. Dostupné z: https://www. euroskop.cz/9047/24848/clanek/analyza-novy-ramec-eu-pro-posileni-pravniho-statu/ 
k článku 2 SEU, takovýto ústavní charakter má. Federální ústava bývá nadřazena státnímu právu a podle toho je též přímo federálními orgány uplatňována. V mechanismu obsaženém v článku 7 SEU zárodky tohoto federálního ústavního př́istupu můžeme spatřovat. Komise svou iniciativou toto federální konstitucionální pojetí dále rozšiřuje nad současný právní rámec daný Smlouvami. S ohledem na charakter Evropské unie, s ohledem na odmítnutí Smlouvy o Ústavě pro Evropu, s ohledem na fakt, že pánem Smluv jsou i nadále členské státy, tento př́stup odmítáme jako aktivistický. Tomuto řešení ostatně nesvědčí ani možné odvozování její legitimity od lidu. Občané členských států se totiž i nadále primárně identifikují se svými státy a př́má politická vazba mezi občanem a Evropskou unii dosud fakticky nevznikla.

Dalším problémem je posun v hodnocení a řešení případného porušení. Stávající stav je totiž takový, že hlavní rozhodovací slovo má Rada nebo Evropská rada. Rozhodování je tedy vedeno na úrovni sobě rovných, tedy mezi členskými státy. Jejich př́stup k řešení problému bude odlišný od přístupu orgánů Komise. Lze předpokládat stejnou motivaci a stejné zapojení, jako $\mathrm{v}$ př́padě jiných porušení smluv, jimiž jsou tyto státy vázány. Motiv řešit problém tak budou mít nejspíše až teprve tehdy, až budou porušením jiného státu osobně dotčeny. Tato skutečnost mimochodem plně reflektuje přetrvávající suverenitu členských států, která možná byla omezena, ale ne odstraněna.

Širším zapojením orgánů Evropské unie, zvlášt' pokud by si skutečně osobovaly též právo udělovat členským státům pokyny, jak správně své vnitřní problémy řešit, dojde k vychýlení v podstatě mechanismu dle článku 7 SEU. Motivace orgánů Evropské unie řešit spory totiž bude odlišná, od motivace členských států. Tyto orgány totiž nebudou sledovat jen vlastní mnohdy sobecké zájmy vyplývající ze vzájemných smluvních závazků. Nepůjde jim jen o prosté dodržování práva. Naopak, lze předpokládat mnohem většî zapojení a podstatně větší důraz též na efektivitu prosazování práva. ${ }^{28}$

\section{Závěr}

Evropskou komisí navržený nový postup EU pro posílení právního státu představuje mechanismus, který v zásadě právně nemění, ale pouze doplňuje mechanismus stávající již upravený článkem 7 SEU. Faktický dopad již ale může být značný, zejména v budoucnu. Je totiž způsobilý narušit současné vzájemné postavení členských států a Evropské unie. Svou povahou představuje další dílčí krok směrem k federativnímu uspořádání Evropské unie, rozšiřuje totiž ústavní charakter určité části unijního práva a předpokládá použití tohoto práva i mimo rámec pravomocí Evropské unie. Dopad je samozrejejě limitován právní nezávazností tohoto mechanismu, což se ale v budoucnu může změnit tím, že tento zatím nezávazný postup bude jako již vyzkoušený kodifikován v primárním

28 MASHAW, J. L. „Federal Issues In and About the Court of Justice of the European Communities“ (1965). Faculty Scholarship Series. Paper 1163. [online]. [cit. 2016-01-23]. Dostupné z: http://digitalcommons.law.yale.edu/fss_papers/1163, s. 31. 
právu. I bez kodifikace a bez právní závaznosti ale může být účinným nástrojem prosazování unijních představ o právním státu svou prostou politickou vahou. V př́padě jeho zavedení však stále dotčeným členským státům zůstává prostor pro jeho ignoraci a trvání na uplatňování výhradně postupu, který je kodifikován článkem 7 SEU. Dlužno dodat, že představené řešení není radikální ani revoluční. Lze si představit i jiné mechanismy, které by vedly ke skutečnému a hmatatelnému omezení suverenity členských států a posílení federálního charakteru Evropské unie, ty by již ale vyžadovaly změnu primárního práva. ${ }^{29} \mathrm{~V}$ optimálním př́padě by pak bylo žádoucí proceduru upravit tak, aby o porušení nerozhodovaly orgány politické a mezivládní, ale orgán soudní jako např. Soudní dvůr EU. Větším zapojením Komise se přitom stávající nevyhovující politický ráz celého mechanismu jen prohlubuje a zhoršuje. Nelze patrně ani akceptovat argument, že by Komisí navržený postup naopak mohl přispět ke snížení možné nejistoty členských států. Článek 7 SEU je totiž poměrně obecný, postup je však popsán dostatečně z pohledu právního. Obecnější formulace dává prostor pro řešení politické. Řešení navržené Komisí nadto nemůže přispívat k vyšší právní jistotě členských států, nebot' samu podstatu, tedy článek 7 SEU, nijak nekonkretizuje. Naopak, dochází k rozšiřování postupů Evropské unie o postupy nové, Smlouvou o Evropské unii nepředvídané. Na závěr se nabízí otázka, zda by Komise za současného stavu, kdy řada předpisů Evropského práva např. v oblasti ostrahy vnějších hranic, či rozpočtové odpovědnosti přestala být dodržována, či se zcela zhroutila, neměla raději směřovat své úsilí do oblastí, které jí dle Smluv věcně náleží, spíše než dále rozšiřovat své aktivity.

29 Viz např. akademická diskuse $\mathrm{k}$ možnosti umožnit jednotlivci odvozované $\mathrm{z}$ unijního občanství př́mo žalovat na porušení základních práva a svobod v př́ípadě dotčení článku 2 SEU. Hovoří se o tzv. „obráceném solange". Viz napry. BUGARIC, B. Protecting Democracy and the Rule of Law in the European Union: The Hungarian Challenge [online]. [cit. 2016-01-23]. Dostupné z: SSRN: http://ssrn.com/abstract=2257935. str. 23.př́padně téź zde http://www.mpil.de/en/pub/research/areas/law-european-union/reverse-solange.cfm. Přesný popis možného postupu ze strany jednotlivce lze včetně rozboru problému lze nalézt též v publikaci MARTINICO, G.. The Tangled Complexity of the EU Constitutional Process The Frustrating Knot of Europe. Abingdon, 2012, s. 156 a násl. 